\title{
DEGRADASI SENYAWA PARAQUAT DALAM PESTISIDA GRAMOXONE® SECARA SONOZOLISIS DENGAN PENAMBAHAN TiO${ }_{2}$-ANATASE
}

\author{
Neila Yenni, Safni, Hamzar Suyani \\ Jurusan Kimia FMIPA Universitas Andalas, Padang
}

\begin{abstract}
Degradation of Paraquat compound in Gramoxone pesticide had been done by sonolysis, ozonolysis, and sonozolysis. Sonolysis methods were performed using an ultrasound VC-1, ozonolysis using a bio-ozone space age sterilizer, and sonozolysis by combining sonolysis and ozonolysis methods. The optimum condition for degradation of $4 \mathrm{mg} / \mathrm{L}$ paraquat by sonolysis was found at temperature $40 \pm 1{ }^{\circ} \mathrm{C}$. Percentage of degradation at optimum condition was $22.80 \%$ with 90 minutes treatment. Whereas, with using ozonolysis method percentage of degradation of paraquat 4 $\mathrm{mg} / \mathrm{L}$ was $50.39 \%$ with 60 minutes treatment. The combination of sonolysis and ozonolysis method simultaneously, these so-called sonozolysis, for degradation of the same compound, extend the percentage of degradation to $45.87 \%$ with only 30 minutes treatment.
\end{abstract}

Keywords: Paraquat, Sonolisis, Ozonolisis

\section{DAFTAR PUSTAKA}

1. M. O'Neil, J. An Encyclopedia of Chemical, Drug and Biological, Merek Indek, $13^{\text {th }}$ ed, Merek and Co. Iuc, USA. No. 5958, 1085, 2001.

2. Departemen Pertanian, Pestisida terdaftar, Dirjen Tanaman Pangan, Jakarta, 2006, 116-117.

3. VT. Riza dan Gayatri, Ingatlah Bahaya Pestisida Bunga Rampai Residu Pestisida dan Alternatifnya, Pestisida Action Net Work (PAN), Jakarta, 1994.

4. X. Xianwhen, S. Hui-xiang, W. Da-hui, Ozonation with Ultrasonic Enhancement of p-nitrophenol wastewater, $J$. Zhejiang Univ. Science B, 5: 319-323, (2005).

5. H. Destalillats, T. W. Anderson, M. R. Hoffmann, Application of Ultrasound in NAPL Remediation Sonochemical Degradation of TCE in Aqueous Surfactant Solution, J. Environ. Sci. Tech., 3019-3024, (2001)

6. J. Stock, Peller, K. vinadgopal, P. V. kamat, Combinative Sonolysis dan
Photocatalysis for Textile Dye Degradation, J. Environ. Sci. Tech., 34: 1747-1750, (2000).

7. S. Arif, Safni, P. P. Roza, Degradasi Senyawa Rhodamin B Secara Sonolisis dengan Penambahan $\mathrm{TiO}_{2}$ Hasil Sintesa Melalui Proses Sol-Gel, J. Ris. kim, 1(1): 64-69, (2007).

8. J. Wang, B. Gue, X. Zhang, Z. Zhang, J. Han, J. Wu, Sonocatalytic Degradation of Methyl Orange in the Present of $\mathrm{TiO}_{2}$ Catalysts and Comparison of Rutile and Anatase, J. Ultrasonics Sonochemistr., 12: 331-337, (2005).

9. Zilfa, Hamzar Suyani, Safni, dan Novesar Jamarun, Degradasi Senyawa Permetrin dengan menggunakan $\mathrm{TiO}_{2-}$ anatase dan zeolit alam secara Sonolisis, J. Ris. Kim., 2(2): 194-199, (2009).

10. Safni, U. Lukman, F. Febriani, Degradasi Zat Warna Sudan I Secara Sonolisis dan Fotolisis Dengan Penambahan $\mathrm{TiO}_{2-}$ anatase, J. Ris. Kim., 1:(2) 164-170, (2008). 